\title{
SURFACE SPECIES INVESTIGATION OF Ni-Fe CATALYSTS OF CO, HYDROGENATION BY TD MS ANALYSIS
}

\author{
R. Meshkini Far, A. Dyachenko, O. Bieda, O. Ischenko \\ Taras Shevchenko Kyiv National University Volodymyrska str., 64, Kyiv, 01601, Ukraine \\ r.meshkinifar@gmail.com
}

The condition of Ni-Fe catalysts' surface was investigated by the method of thermally programmed desorption with mass spectral analysis of desorbed particles (TD MS). TD spectra indicated the desorption of $\mathrm{CO}_{2}(\mathrm{~m} / \mathrm{z}=44), \mathrm{CO}(\mathrm{m} / \mathrm{z}=28)$ and $\mathrm{H}_{2} \mathrm{O}(\mathrm{m} / \mathrm{z}=18)$ particles from the surface of samples with high and low catalytic activity in the reaction of $\mathrm{CO}_{2}$ hydrogenation. Intermediate compounds $\mathrm{CHO}^{*}, \mathrm{CH}_{2} \mathrm{O}^{*}$ were not observed in the TD profiles for all investigated catalysts. On the basis of catalytic performance results and thermal desorption data it can be suggested that process of $\mathrm{CO}_{2}$ hydrogenation over Ni-Fe catalysts proceeds via direct hydrogenation of $\mathrm{CO}_{2}$ to $\mathrm{CH}_{4}$.

Keywords: Ni-Fe catalysts; $\mathrm{CO}_{2}$ hydrogenation; catalytic activity; TD-MS analysis.

\section{Introduction}

Carbon dioxide is a component widely existing in nature, but is regarded as an air pollutant, so it's needed to reduce the concentration of it in the nature. One of the obvious ways is to reduce pollution by $\mathrm{CO}_{2}$ by means of the catalytic conversion of waste $\mathrm{CO}_{2}$ emitted from, i.e., enterprise. Among of various methods, hydrogenation of carbon dioxide not only reduces carbon dioxide but also produces methane. Methane is the cleanest fossil fuel for electricity production $[1-3]$. Therefore, developing a catalyst that can improve activity, selectivity, economic and environmental requirements to industrialize the process for carbon dioxide hydrogenation is very important. Carbon dioxide molecule is kinetically and thermodynamically stable so the reaction of carbon dioxide hydrogenation is endothermic and calls for use of efficient catalysts to obtain high methane yield. This reaction has been studied over metal catalysts $\mathrm{Ni}, \mathrm{Fe}, \mathrm{Co}, \mathrm{Cu}, \mathrm{Ru}$, and $\mathrm{Rh}$ that were supported on $\mathrm{SiO}_{2}, \mathrm{Al}_{2} \mathrm{O}_{3}, \mathrm{ZrO}_{2}, \mathrm{TiO}_{2}$, and $\mathrm{CeO}_{2}$ metal oxides [3 - 7]. According to the literature, among these catalysts, the iron unlike the nickel has low activity in catalysis of the hydrogenation of $\mathrm{CO}_{2}[8,9]$, although a computational screening study based on density functional theory calculations has indicated that Ni-Fe catalysts could be more active than the pure $\mathrm{Ni}$ catalyst [10]. So, the catalytic properties of bimetallic Ni-Fe catalyst seem to be promising for using in environmentally safe process.

It is important to study the surface properties of $\mathrm{Ni}-\mathrm{Fe}$ system for understanding of mechanism for $\mathrm{CO}_{2}$ hydrogenation. In the previous work we investigated catalytic structure and showed the efficiency of using Ni-Fe catalysts in the $\mathrm{CO}_{2}$ hydrogenation $[11,12]$. In this work, surface species adsorption properties of Ni-Fe catalysts of $\mathrm{CO}_{2}$ hydrogenation with different $\mathrm{Ni}$ :Fe ratio were investigated by TD MS analysis.

\section{Experimental}

Synthesis of $\mathrm{Ni}-\mathrm{Fe}$ catalysts in the range of $0-100$ mass $\%$ of nickel, with respective addition of iron was carried out by dissolving the proper amount of metals in nitric acid with subsequent 
precipitation by ammonia and drying in air for 4 hours at $300{ }^{\circ} \mathrm{C}$. Prior to the catalytic reaction, each catalyst was reduced with a mixed stream of hydrogen and helium at a ratio of 50:50 vol. \% at $300{ }^{\circ} \mathrm{C}$ for 4 hours. The optimal temperature for catalysts reduction was determined with thermogravimetric method [11].

Methane production test for bimetallic Ni-Fe catalysts was carried out in a continuous flow fixed-bed reactor with $8 \mathrm{~mm}$ in diameter. Carbon dioxide and hydrogen were continuously fed into the reactor balanced with helium. Feed composition was fixed at 2 vol. $\%$ of $\mathrm{CO}_{2}, 55$ vol. \% of $\mathrm{H}_{2}$ and $43 \mathrm{vol} . \%$ of He. The reaction was carried out at the pressure of $0,1 \mathrm{MPa}$ in the temperature range of $30-500{ }^{\circ} \mathrm{C}$. Reaction products were analyzed by an online gas chromatograph (Shimadzu GC-2014) equipped with a thermal conductivity detector (TCD) using a molecular sieves packed column for the separation of $\mathrm{CO}_{2}, \mathrm{CO}, \mathrm{CH}_{4}$. To compare the catalytic activities for the series, we chose the temperature of $350{ }^{\circ} \mathrm{C}$ at which the most active samples reached a steady maximum of activity.

To study the desorbed particles from the surface of the catalyst a quadrupole mass spectrometer (MS) MX 7304 ("Selmi", Ukraine) was used. The reduced catalyst was exposed under hydrogenation experiment conditions. The catalyst then was cooled to ambient temperature, and then heated linearly in vacuum at $14 \%$ min up to $800{ }^{\circ} \mathrm{C}$ while the effluent stream was analyzed for $\mathrm{m} / \mathrm{z}$ range of $10-100$ by on-line MS MX7304A.

\section{Results and discussion}

In the first part of our research, the catalytic behavior of bimetallic Ni-Fe catalysts in the range of concentrations from 0 to $100 \%$ of nickel was studied [11]. The chemical composition and the results of the catalytic performance tests of the $\mathrm{Ni}-\mathrm{Fe}$ catalysts under investigation are summarized in Table 1. Based on the results, the higher yield of $\mathrm{CH}_{4}$ is observed at the temperature of $300-400{ }^{\circ} \mathrm{C}$ and it drops sharply at the temperature of $500{ }^{\circ} \mathrm{C}$. The maximum $\mathrm{CH}_{4}$ yields reaching $66.5 \%$ were obtained at $350{ }^{\circ} \mathrm{C}$ for $\mathrm{Ni}_{80} \mathrm{Fe}_{20}$ catalyst.

Table 1. The chemical composition and the results of catalytic performance test of Ni-Fe catalysts in the reaction of $\mathrm{CO}_{2}$ hydrogenation

\begin{tabular}{|c|c|c|c|c|c|c|c|c|c|c|c|c|c|}
\hline \multirow{2}{*}{\multicolumn{2}{|c|}{$\begin{array}{c}\text { Sample } \\
\text { mass \% }\end{array}$}} & \multirow{3}{*}{$\begin{array}{c}\text { Reaction } \\
\text { product }\end{array}$} & \multirow{2}{*}{\multicolumn{4}{|c|}{$\begin{array}{c}\text { Yield, } \% \\
\text { Temperature, }{ }^{\circ} \mathrm{C}\end{array}$}} & \multirow{2}{*}{\multicolumn{2}{|c|}{$\begin{array}{l}\text { Sample } \\
\text { mass \% }\end{array}$}} & \multirow{3}{*}{$\begin{array}{l}\text { Reaction } \\
\text { product }\end{array}$} & \multicolumn{4}{|c|}{ Yield, \% } \\
\hline & & & & & & & & & & \multicolumn{4}{|c|}{ Temperature, ${ }^{\circ} \mathrm{C}$} \\
\hline $\mathbf{N i}$ & $\mathbf{F e}$ & & 300 & 350 & 400 & 500 & $\mathbf{N i}$ & $\mathbf{F e}$ & & 300 & 350 & 400 & 500 \\
\hline \multirow{2}{*}{100} & \multirow{2}{*}{0} & $\mathrm{CH}_{4}$ & 32 & 53.8 & 60.1 & 5.2 & \multirow{2}{*}{70} & \multirow{2}{*}{30} & $\mathrm{CH}_{4}$ & 50.8 & 62 & 59.1 & 2 \\
\hline & & $\mathrm{CO}$ & 3.8 & 7 & 8.5 & 5 & & & $\mathrm{CO}$ & 6.2 & 4.1 & 4.9 & 5 \\
\hline \multirow{2}{*}{90} & \multirow{2}{*}{10} & $\mathrm{CH}_{4}$ & 65.8 & 65 & 60.4 & 7.9 & \multirow{2}{*}{50} & \multirow{2}{*}{50} & $\mathrm{CH}_{4}$ & 27.8 & 40 & 41.4 & 7.4 \\
\hline & & $\mathrm{CO}$ & 1.3 & 1.4 & 1.4 & 1.3 & & & $\mathrm{CO}$ & 2.3 & 2.6 & 3.9 & 2.4 \\
\hline \multirow{2}{*}{80} & \multirow{2}{*}{20} & $\mathrm{CH}_{4}$ & 65.8 & 66.5 & 61.9 & 9.9 & \multirow{2}{*}{20} & \multirow{2}{*}{80} & $\mathrm{CH}_{4}$ & 15 & 35 & 15 & 4.5 \\
\hline & & $\mathrm{CO}$ & 2 & 1.5 & 1.5 & 1.5 & & & $\mathrm{CO}$ & 2.2 & 2.5 & 4.5 & 2.3 \\
\hline \multirow{2}{*}{75} & \multirow{2}{*}{25} & $\mathrm{CH}_{4}$ & 6.4 & 15 & 1.1 & 2.1 & \multirow{2}{*}{0} & \multirow{2}{*}{100} & $\mathrm{CH}_{4}$ & 0 & 0 & 1.5 & 6.6 \\
\hline & & $\mathrm{CO}$ & 10.9 & 18 & 9.1 & 1.3 & & & $\mathrm{CO}$ & 10.8 & 36.4 & 34.8 & 4.2 \\
\hline
\end{tabular}

Apart from methane, carbon monoxide is observed as a reaction product in all cases. However, a $\mathrm{CO}$ production increase is associated with a methane production decrease. The highest yield of $\mathrm{CH}_{4}$ was observed for the sample with 80 mass. $\%$ of $\mathrm{Ni}\left(\mathrm{Ni}_{80} \mathrm{Fe}_{20}\right)$, whereas for the sample with 75 mass. \% of $\mathrm{Ni}\left(\mathrm{Ni}_{75} \mathrm{Fe}_{25}\right)$ catalytic performance drops sharply and reaches a relative minimum in $\mathrm{CO}_{2}$ hydrogenation. While all other catalysts always show higher selectivity 
to $\mathrm{CH}_{4}$ than to $\mathrm{CO}, \mathrm{Ni}_{75} \mathrm{Fe}_{25}$ catalyst gives rise to higher selectivity for $\mathrm{CO}$ than for $\mathrm{CH}_{4}$. According to the studies of Fe-Ni alloys [13], when nickel content is in a concentration range of less than $72 \%$ or more than $77 \%$, two-phase regions with $\gamma$-phase and intermetallic $\mathrm{FeNi}_{3}$ are observed. But in the composition range $72-77 \%$ of nickel, there is only $\mathrm{FeNi}_{3}$ compound in the form of a homogeneous solid solution [13].

The observed effect of the catalytic activity increase (increase of methane yield at the same conditions) in the $\mathrm{Ni}_{80} \mathrm{Fe}_{20}$ sample is related to the presence of phase interfaces in the catalytic systems. It is known that the catalytic activity of mixtures depends on the phase composition. The heterogeneous mixtures have higher catalytic activity then homogeneous phase due to interface properties. Moreover, the catalytic properties of the mixtures depend on the presence of the organized structures and chemical compounds in them. The formation of intermetallic compounds reduces the catalytic activity of the system [14].

Among the studied samples we have selected pure nickel, pure iron, the best $\left(\mathrm{Ni}_{80} \mathrm{Fe}_{20}\right)$ and the worst $\left(\mathrm{Ni}_{75} \mathrm{Fe}_{25}\right)$ catalysts. Desorption of particles from the surface active site of these samples was investigated by TD MS analysis. For $\mathrm{Ni}_{80} \mathrm{Fe}_{20}, \mathrm{Ni}_{75} \mathrm{Fe}_{25}$ and $\mathrm{Ni}$ samples methane and carbon monoxide are the products of hydrogenation process, while in the case of pure Fe sample methane is not formed at all, and the only carbon monoxide is product of $\mathrm{CO}_{2}$ and $\mathrm{H}_{2}$ interaction.

The experimental data shows that the desorption peaks of $\mathrm{CO}, \mathrm{CO}_{2}$ and $\mathrm{H}_{2} \mathrm{O}$ are symmetrical (Fig.). It suggests that $\mathrm{CO}, \mathrm{CO}_{2}$, and $\mathrm{H}_{2} \mathrm{O}$ molecules are formed near the surface by recombination of the corresponding atoms. It means that the carbon, oxygen and hydrogen atoms exist separately on the catalyst surface [15]. Generally, if a process undergoes a formal kinetics

$$
-\frac{d \theta}{d t}=k \theta^{n}
$$

where $\theta$ is surface coverage and $n$ is the kinetic order of the process, in the case of linear heating the peak (rate versus temperature) must be asymmetrical for $n=1$ and nearly symmetrical for $n=2$ [15]. The symmetrical form of all desorption peaks, even for CO, suggests the second order of desorption, thus, the recombination of separate atoms into the $\mathrm{CO}$ molecule.

TD data of the maximum peak temperature $\left(\mathrm{T}_{\mathrm{m}}\right)$ can be divided into three ranges (see Table 2): $80-180^{\circ} \mathrm{C}$ - particles weakly bound to the surface; $200-350^{\circ} \mathrm{C}$ - particles with desorption temperature close to reaction of hydrogenation temperature; $400-500^{\circ} \mathrm{C}$ - particles firmly bound to catalyst surface.

Table 2. The peaks temperature $\left(\mathrm{T}_{\mathrm{m}}\right)$ of desorbed particles from the samples' surface

\begin{tabular}{|c|c|c|c|}
\hline \multirow{2}{*}{ Sample } & \multicolumn{3}{|c|}{ Particle } \\
\hline & $\mathrm{CO}(\mathrm{m} / \mathrm{z}=28)$ & $\mathrm{CO}_{2}(\mathrm{~m} / \mathrm{z}=44)$ & $\mathrm{H}_{2} \mathrm{O}(\mathrm{m} / \mathrm{z}=18)$ \\
\hline $\mathrm{Ni}_{80} \mathrm{Fe}_{20}$ & $100,140,290,440$ & $90,145,300,440$ & 90,210 \\
\hline $\mathrm{Ni}_{75} \mathrm{Fe}_{25}$ & 300 & 300 & 90,210 \\
\hline $\mathbf{N i}$ & $245,300,440$ & $100,150,240,300$ & $90,175,230$ \\
\hline $\mathrm{Fe}$ & $100,260,440$ & $100,270,440$ & 90 \\
\hline
\end{tabular}



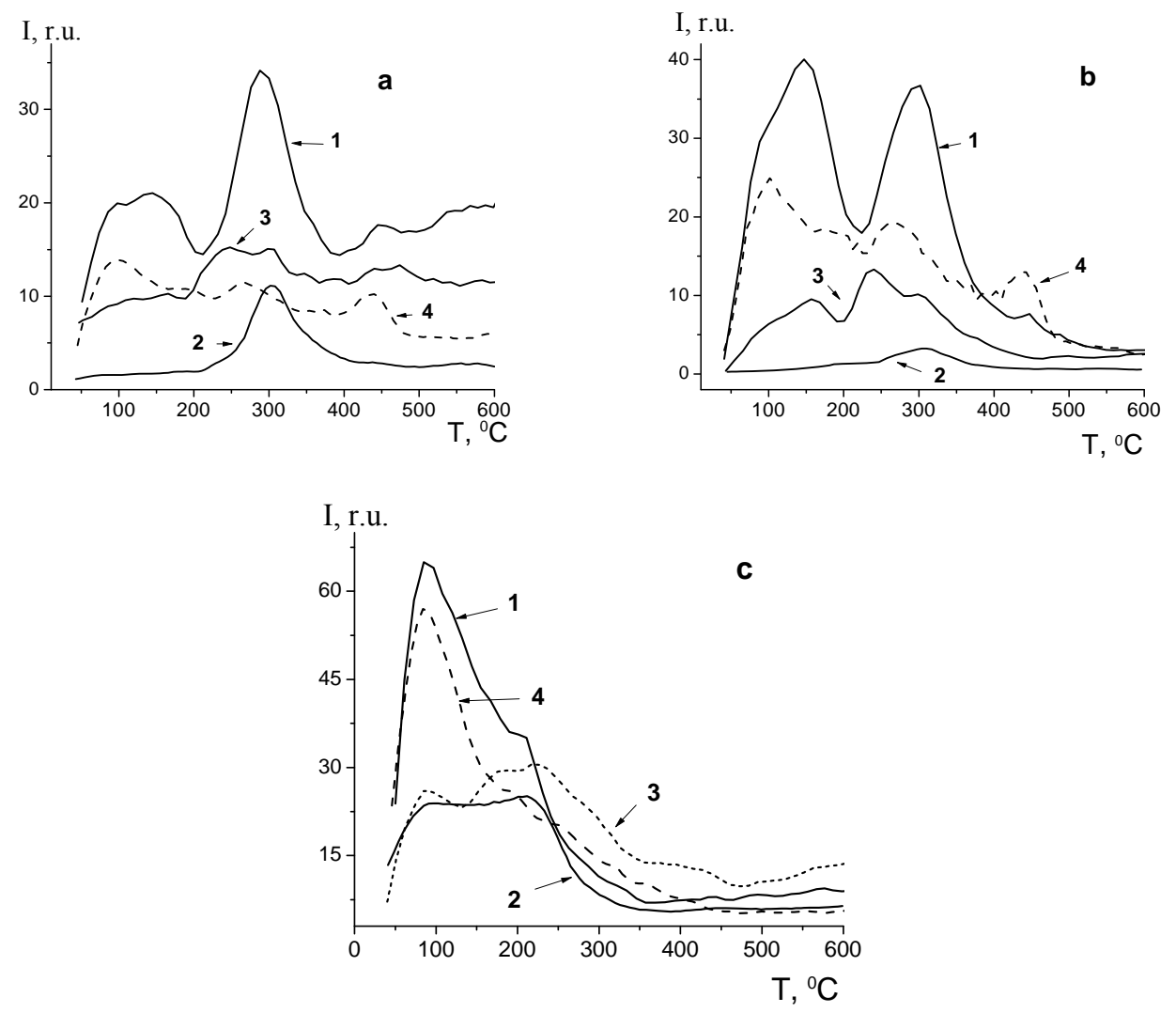

Fig. TD profile of $\mathrm{CO}(\mathrm{a}), \mathrm{CO}_{2}(\mathrm{~b})$ and $\mathrm{H}_{2} \mathrm{O}$ (c) particles for the samples: $1-\mathrm{Ni}_{80} \mathrm{Fe}_{20}$, $2-\mathrm{Ni}_{75} \mathrm{Fe}_{25}, 3-\mathrm{Ni}$ and $4-\mathrm{Fe}$.

TD spectra of $\mathrm{CO}$ and $\mathrm{CO}_{2}$ from surface of $\mathrm{Ni}_{75} \mathrm{Fe}_{25}$ catalyst has the only maximum at $300{ }^{\circ} \mathrm{C}$, but for surface of $\mathrm{Ni}_{80} \mathrm{Fe}_{20}$ there are peaks in the range of $90-440{ }^{\circ} \mathrm{C}$. TD maximum at $130^{\circ} \mathrm{C}$ can be attributed to the weak physical adsorption.

TD spectra of $\mathrm{CO}$ from surface of inactive $\mathrm{Ni}_{75} \mathrm{Fe}_{25}$ catalyst has the greater intensity than for $\mathrm{CO}_{2}$, in good agreement with the results of the catalytic performance (Table 1) which show that between all of the tested catalysts the lowest yield of $\mathrm{CH}_{4}(6 \%)$ and the highest yield of $\mathrm{CO}$ $(11 \%)$ at $300{ }^{\circ} \mathrm{C}$ (see Table 1) are observed for $\mathrm{Ni}_{75} \mathrm{Fe}_{25}$ catalyst. Thus, it can be assumed that $\mathrm{CO}_{2}$, which is adsorbed on the active site, breaks up into $\mathrm{CO}$ and $\mathrm{O} . \mathrm{CO}$ is firmly chemisorbed on the active site and inhibits the progress of $\mathrm{CO}_{2}$ hydrogenation process. In contrast, the intensity of the TD spectra of $\mathrm{CO}_{2}$ and $\mathrm{CO}$ from surface of active $\mathrm{Ni}_{80} \mathrm{Fe}_{20}$ catalyst is almost the same at $300^{\circ} \mathrm{C}$. Based on these results, we can conclude that process of $\mathrm{CO}_{2}$ hydrogenation over $\mathrm{Ni}-\mathrm{Fe}$ catalysts proceeds via direct hydrogenation of $\mathrm{CO}_{2}$ to $\mathrm{CH}_{4}$. The chemisorbed $\mathrm{CO}_{2}$ on the catalyst active centers, which are located at the interface boundary, is dissociated completely to $\mathrm{C}^{*}$ ads and $\mathrm{O}^{*}$ ads. Then adsorbed carbon quickly reacts with available hydrogen (adsorbed on the catalysts surface or from the gas phase) and $\mathrm{CH}_{4}$ is desorbed in result. Water is formed by the similar mechanism from the adsorbed oxygen and available hydrogen. The limiting step in this process is the formation of $\mathrm{H}_{2} \mathrm{O}$ from the adsorbed $\mathrm{OH}^{*}$ ads group with adsorbed $\mathrm{H}^{*}$ ads. The formation of $\mathrm{CH}_{4}$ is fast, so in the TD spectra $\mathrm{CH}^{*}, \mathrm{CH}_{2}{ }^{*}, \mathrm{CH}_{3}{ }^{*}$ intermediates are not recorded. TD MS analysis of surface species in active and inactive samples showed that $\mathrm{CO}_{2}$ hydrogenation process onto $\mathrm{Ni}-$ Fe catalysts has the mechanism that does not involve oxygen-containing intermediates. If the 
process proceeds via an intermediate $\mathrm{CO}$, the TD spectra of intermediates, namely $\mathrm{CHO}^{*}, \mathrm{CH}_{2} \mathrm{O}^{*}$ would have been recorded. The data shown in Fig. 1c indicate that there is no peak of water on the TD spectrum from surfaces of $\mathrm{Ni}_{80} \mathrm{Fe}_{20}$ and $\mathrm{Ni}_{75} \mathrm{Fe}_{25}$ at $300{ }^{\circ} \mathrm{C}$, and this fact confirms that the oxygen is generated by dissociation of $\mathrm{CO}_{2}$ rather than by dissociation of water at this temperature. These results are in good agreement with the mechanism that was reported in the previous literature [16].

From the results of catalytic performance and thermal desorption one can suggest the following mechanism for the reaction of $\mathrm{CO}_{2}$ hydrogenation over $\mathrm{Ni}-\mathrm{Fe}$ catalysts:

1. $\mathrm{CO}_{2}+[] \rightarrow[\mathrm{O} \ldots . . \mathrm{C} \ldots . . \mathrm{O}]$

2. $[\mathrm{O} \ldots . . . \mathrm{C} \ldots . . \mathrm{O}] \rightarrow[\mathrm{C}]+2[\mathrm{O}]$

3. $\mathrm{H}_{2}+2[] \rightarrow 2[\mathrm{H}]$

4. $[\mathrm{C}]+[\mathrm{H}] \rightarrow[\mathrm{CH}]+[]$

5. $[\mathrm{CH}]+[\mathrm{H}] \rightarrow\left[\mathrm{CH}_{2}\right]+[]$

6. $\left[\mathrm{CH}_{2}\right]+[\mathrm{H}] \rightarrow\left[\mathrm{CH}_{3}\right]+[]$

7. $\left[\mathrm{CH}_{3}\right]+[\mathrm{H}] \rightarrow \mathrm{CH}_{4}+2[]$

8. $[\mathrm{O}]+[\mathrm{H}] \rightarrow[\mathrm{OH}]+[]$

9. $[\mathrm{OH}]+[\mathrm{H}] \rightarrow \mathrm{H}_{2} \mathrm{O}+2[]$,

where [ ] - free space on the surface of the catalyst; formation of methane (steps 4-7) is fast and formation of water (steps 8-9) is slow.

\section{Conclusion}

A series of the Ni-Fe catalysts were prepared by the co-precipitation of the hydroxides. All samples were reduced in the same conditions, and they were applied to the methane production from $\mathrm{CO}_{2}$ and $\mathrm{H}_{2}$. Among the tested catalysts, $\mathrm{Ni}_{80} \mathrm{Fe}_{20}$ showed the best catalytic performance in terms of conversion of $\mathrm{CO}_{2}$ and yield for $\mathrm{CH}_{4}$. It has been shown that the conversion of $\mathrm{CO}_{2}$ to methane is significantly increased over the bimetallic nickel-iron catalysts compared to the pure nickel catalyst. The experiments illustrate that the best catalysts have a Ni/Fe ratio above 4 . TD MS analysis of active and inactive samples' surface showed that $\mathrm{CO}_{2}$ hydrogenation process over $\mathrm{Ni}-\mathrm{Fe}$ catalysts has the mechanism that does not involve oxygen-containing intermediates. Based on results of catalytic performance and thermal desorption one can suggest that process of $\mathrm{CO}_{2}$ hydrogenation over Ni-Fe catalysts proceeds via direct hydrogenation of $\mathrm{C}$ atom (formed in $\mathrm{CO}_{2}$ dissociation) to $\mathrm{CH}_{4}$.

\section{References}

1. Mikkelsen M., Jorgensen M. and Krebs F.C. The teraton challenge. The review of fixation and transformation of carbon dioxide// Energy Environ. Sci. - 2010. - V. 3. P. 43-81.

2. Landau M.V., Vidruk R., Herskowitz M. Sustainable production of green feed from carbon dioxide and hydrogen // Chem. Sus. Chem. - 2014. - V. 7. - P. 785-794.

3. Wang W., Wang S., Ma X., Gong J. Recent advances in catalytic hydrogenation of carbon dioxide // Chem. Soc. Rev. - 2011. V. 40, N 7. P. 3703-3727.

4. Brooks K.P., Hu J. L., Zhu H.Y., Kee R. J. Methanation of $\mathrm{CO}_{2}$ over Ni catalyst // Chem. Eng. Sci. - 2007. V. 62. - P. 1161-1170.

5. Rodriguez J.A., Hanson J.C., Stacchiola D., Senanayake S.D. In situ/operando studies for the production of hydrogen through the water-gas shift on metal oxide catalysts // Journal of Phys Chem Chem Phys. - 2013. - V. 15, N. 29. - P. 12004-25. 
6. Janke C., Duyar M.S., Hoskins M. Catalytic and adsorption studies for the hydrogenation of $\mathrm{CO}_{2}$ to methane // Applied Catalysis B: Environmental. - 2014. - V.152. V. 184-191.

7. Aaron D., Tsouris C., Separation of $\mathrm{CO}_{2}$ from flue gas // Science and Technology. -2005.-V.40. - P. 321-348.

8. Lok M. Synthesis of Solid Catalysts. Edited by. Kren P. dejong. - WILEY-. VCH, 2009. $422 \mathrm{p}$

9. Cubeiro M.L., Morales H., Goldwasser M.R., Perez-Zurita M.Z., Gonzales-Jimenez F., Urbina de N C. Hydrogenation of carbon oxides over $\mathrm{Fe} / \mathrm{Al}_{2} \mathrm{O}_{3}$ catalysts // Applied Catalysis A: General. - 1999. - V. 189. - P. 87-97.

10. Andersson M.P., Bligaard T., Kustov A.L., Larsen K.E., Greeley J., Johannessen T., Christensen C.H. A molecular view of heterogeneous catalysis // J. Catal. - 2006. - V. 239. P. 501-506.

11. Meshkini Far R., Ischenko O., Zakharova T., Dyachenko A. Activity of Ni-Fe catalysts in the reaction of $\mathrm{CO}_{2}$ hydrogenation // Bulletin of Taras Shevchenko Kyiv National University. - 2016. - V. 52. - P. 63-65.

12. Ischenko O.V, Meshkini Far R., Bieda O.A., Dyachenko A.G., Zakharova T.M., Filonenko M.M. Ni-Fe Catalytic Systems for reaction of $\mathrm{CO}_{2}$ methanation // UKR Chemistry Journal. 2017. - V. 83, N. 3. - P. 50-55.

13. Yang C.W., Williams D.B. A Revision of the Fe-Ni Phase Diagram at Low Temperatures // Journal of Phase Equilibria. - 1996. - V. 17, N. 6. - P. 522-531.

14. Tovbin M.V. Physical chemistry. (Ed. "Vyshcha shkola" . 1975)

15. Roberts M., Mackie C. Chemistry of the metal-gas interface. (M: Mir. 1981).

\title{
ДОСЛІДЖЕННЯ ЧАСТИНОК НА ПОВЕРХНІ Ni-Fe КАТАЛІЗАТОРІВ ГІДРОГЕНУВАННЯ СО ТД МС АНАЛІЗУ
}

\author{
Р. Мешкініфар, А. Дяченко, О. Бсда, О. Іщенко \\ Київський національний університет імені Тараса Шевченка \\ вул. Володимирська, 64, Київ, 01601, Україна \\ r.meshkinifar@gmail.com
}

Методом термопрограмованої десорбиійної мас-спектрометрії (ТД МС) досліджено стан поверхні $\mathrm{Ni}-\mathrm{Fe}$ каталізаторів реакиї гідрогенування $\mathrm{CO}_{2}$. $\mathrm{Ha}$ TД спектрах зареєстровано десорбиію частинок $\mathrm{CO}_{2}(\mathrm{~m} / \mathrm{z}=44), \mathrm{CO}(\mathrm{m} / \mathrm{z}=28) \mathrm{ma}_{2} \mathrm{O}(\mathrm{m} / \mathrm{z}=18)_{3}$ поверхні зразків, щзо проявили високу та низьку каталітичну активність у реакиіі гідрогенування $\mathrm{CO}_{2}$. Проміжні сполуки $\mathrm{CHO}^{*}, \mathrm{CH}_{2} \mathrm{O}^{*}$ не спостерігалися на ТД профілях для всіх досліджуваних зразків. На основі результатів каталітичної активності та термічної десорбиії зроблено припущення, що прочес конверсії $\mathrm{CO}_{2}$ в метан на $\mathrm{Ni}$-Fe каталізаторах відбувається через пряме гідрогенування карбону без утворення проміжних кисневмісних сполук. 


\title{
ИССЛЕДОВАНИЕ ЧАСТИЦ НА ПОВЕРХНОСТИ Ni-Fe КАТАЛИЗАТОРОВ ГИДРОГЕНИРОВАНИЯ СО 2 МЕТОДОМ ТД МС АНАЛИЗА
}

\author{
Р. Мешкинифар, А. Дяченко, А. Беда, Е. Ищенко \\ Киевский национальный университет имени Тараса Шевченко \\ ул. Владимирская, 64, Киев, 01601, Украина \\ r.meshkinifar@gmail.com
}

\begin{abstract}
Методом термопрограмированной десорбиионной масс-спектрометрии (ТД MC) исследовано состояние поверхности $\mathrm{Ni}-\mathrm{Fe}$ катализаторов реакиии гидрогенирования $\mathrm{CO}_{2}$. По ТД спектрах зарегистрировано десорбиию частичек $\mathrm{CO}_{2}(\mathrm{~m} / \mathrm{z}=44), \mathrm{CO}(\mathrm{m} / \mathrm{z}=28) \mathrm{ma}$ $\mathrm{H}_{2} \mathrm{O}(\mathrm{m} / \mathrm{z}=18)$ с поверхности образиов, которые показали высокую и низкую активность в реакции гидрогенирования $\mathrm{CO}_{2}$. Образование промежуточных соединений $\mathrm{CHO}^{*}, \mathrm{CH}_{2} \mathrm{O}^{*}$ не наблюдалось ни для одного из исследованных образиов. Из полученных результатов по изучению каталитической активности и термической десорбции сделано предположение, что процесс конверсии $\mathrm{CO}_{2}$ в метан на $\mathrm{Ni}-\mathrm{Fe}$ катализаторах происходит путем прямого гидрогенирования атомарного углерода без образования промежуточных кислородсодержащих соединений.
\end{abstract}

